\title{
The Uncanny “Religious” Refugee: a Post-Secular Perspective on Ethics of Hospitality
}

\author{
Paolo Gomarasca
}

The aim of this chapter is to show and analyze the unethical ambivalence of the dominant narratives about the events of migration, especially in the case of (forced) displacement. On the one hand, refugees are criminalized and targeted as a dangerous threat to border security. Refoulement practices and concentration camp-like conditions in some refugee camps are the "zoopolitical" effect of this paranoid rhetoric. On the other hand, counter-narratives portray refugees as helpless, passive victims. The effect of this idealized rhetoric is associated with a wide range of relief actions, such as safe zones, humanitarian entry visas, resettlement in solidarity, residency permits and other forms of what some theorists call biopolitical care. The paradox is that these two stereotyped imaginaries of forced displacement are the two faces of the same unethical process of dehumanization: in both cases, refugees are objects of other people's interpretations and actions. But the key point is that, in this process of dehumanization, religion is often politicized and plays an instrumental part in justifying the two opposite narratives: the dangerous refugee is a (bad) Muslim, which threatens Christian civilization; the vulnerable refugee is a (good) victimized Christian or a (good) poor Muslim, who wait patiently in camps for Western salvation.

An ethics of hospitality is possible only under two conditions. Firstly, we need to de-instrumentalize religion and analyze the real, multi-dimensional role of religion in refugees' experience: the role as a root cause of displacement, in the countries of departure; and the role as a source of resiliency and as a key factor, which can both facilitate and impede integration processes in the countries of arrival. Secondly, we need to give back to the refugees their human subjectivity, which means enabling them to enter the discourse and express their subjective outlook on their own experience of forced displacement and on the importance of their religious belonging.

The political effect of this post-secular hospitality is a discursive act that creates a public space, where social ties can be (re-)built. Religion, in this context of re-humanization, can be an integral part of refugees' public space making, along four main lines of research: 
1) identity, that focuses on individual and collective processes of shaping and reshaping some forms of self-definition, based on religious beliefs and values;

2) religious freedom, which legitimizes the pluralistic involvement of (religious) identities in public life;

3) citizenship, which is not tied to rigid national territoriality but includes fluidity of borders and multiple (religious) identities and loyalties;

4) common good, i.e. a multi-religious social capital, generated by the new citizens and their desire to participate in their new society of settlement.

\section{Agents of Transgression}

The first ethical step to be taken when talking about refugees is to acknowledge the transgressive character of their arrival: displaced persons, especially in the case of religious refugees, cross the border by force, they try all they can, they negotiate (with borders guards, smugglers, fishermen, and other actors (Mainwaring, 2016)) and finally break in, under the effect of the terror of persecution. Their sudden appearance on the European scene unleashes anxiety. Religious refugees embody danger, they are perceived as carriers of trauma, which is associated with "a simplistic trope about violence: yesterday's victim may become tomorrow's perpetrator" (Varvin, 2017: 360). The Syrian flux in 2015 is emblematical: an incredibly effective right-wing message has framed the immigration crisis as a "Muslim threat" (Forlenza, Turner 2018: 28), perhaps because too many Europeans (and Americans) know that most of IsIs's victims are Muslim, not only Shia, as would have seemed logical (Flescher, 2017: 175). ${ }^{1}$ It is not by chance that the vast majority of the refugees registered by UNHCR are Sunni Muslims (Eghdamian, 2015). Sure, it could be argued that Sunni are not, in a strict legal sense, religious refugees. ${ }^{2}$ Besides, they are not a

1 With respect to the Syrian conflict, it is worth pointing out that it is precisely a conflict with ancient religious roots, as Tomass argued: "for more than a millennium, the tradition of attributing infidelity (takfir) and apostasy (irtidād) to religious communities that did not conform to the dominant Sunni orthodoxy led, in the best case, to the marginalization of those communities" (Tomass, 2016: 5).

2 It is worth mentioning that, while the law is clear that religious persecution constitutes grounds for asylum, applications on these grounds are very few. Partly because religious minorities are generally reluctant to denounce religious discriminations: "fearing for their safety, they often hide their identities to avoid reprisal attacks based on sectarian tensions" (Eghdamian, 2015). Partly because UNHCR tends to prioritize refugee claims based on basic human neEds Things do not change, even if the Muslim "invaders" decide to convert to Christian faith: when applying for asylum, they may be treated with suspicion, because "the 
minority, as in the case of Christian, Druze, Ismaili and other Muslim and nonMuslim minority religious people and families fleeing Syria. But the truth is that religious persecution is following them and waiting for them at Europe's borders. An interesting case-study relates to Bulgarian vigilantes, patrolling the borders of the EU, between 2014 and 2016. Among these far-rights activists and defenders of Europe, there was an unexpected "hero", a Bulgarian Muslim who explained his rationale, during an interview: "we want to stop an Islamic invasion" (Rexhepi, 2018: 2223).

All this seems to confirm our starting point: the religious refugee is inseparable from the theme of the (unexpected) trespasser, which materializes as an "illegal body", to be carefully controlled (Ajana, 2013; Lindskov Jacobsen, 2017). As Nancy would point out, this trauma of intrusion is intrinsically bind to the stranger in general: "there must be something of the intrus in the stranger; otherwise, the stranger would lose its strangeness" (Nancy 2002: 1). However, this evidence is not as simple as it appears at first sight and that is why it deserves a further inquiry.

Let us consider now the famous scene of intrusion in The uncanny guest, an early tale by Hoffmann, originally published in 1819:

Into a quiet happy group of friends, just when supernatural matters were forming the subject of conversation, there suddenly came a stranger, who struck everyone as being uncanny and terrifying, notwithstanding his apparent everydayness, and seeming belonging to the common level. (Hoffmann, 1892: 141)

In his analysis, Freud explained the shocking effect triggered by the Hoffmannian guest with the ambivalence of his entrance, reaching the conclusion that the uncanny (Unheimlich) is in some way or another a sub-species of familiar

genuineness of their conversion is often called into question" (Bielefeldt et al., 2016: 62). Christian convert asylum-seekers (but also Christians) are asked detailed factual "Bible trivia" questions, such as: "Can you name the twelve apostles?" "When is Pentecost?" "What fruit did Adam eat?" (APPG and AAG, 2016:3) Moreover, "extraditions of converts to their countries of origin, even in the face of obvious risks of persecution, have at times been justified with the cynical recommendation that they could simply "conceal" their new faith" (Bielefeldt et al., 2016: 62). 
TABLE 2.1 Countries where nationalist political parties or politicians targeted religious groups in 2016, and religious groups that were targeted

\begin{tabular}{|c|c|c|}
\hline Country & Region & Targeted religious group \\
\hline United States & Americas & Muslims \\
\hline Burma (Myanmar) & Asia-Pacific & Muslims \\
\hline India & Asia-Pacific & Christians, Muslims, Hindus \\
\hline Nepal & Asia-Pacific & Christians \\
\hline New Zealand & Asia-Pacific & Muslims \\
\hline Philippines & Asia-Pacific & Jews, Christians \\
\hline Sri Lanka & Asia-Pacific & $\begin{array}{l}\text { Christians, Muslims, } \\
\text { Non-Buddhists }\end{array}$ \\
\hline Austria & Europe & Muslims \\
\hline Bulgaria & Europe & Christians \\
\hline Denmark & Europe & Muslims \\
\hline Estonia & Europe & Muslims \\
\hline Finland & Europe & Muslims \\
\hline France & Europe & Muslims \\
\hline Germany & Europe & Muslims, Jews \\
\hline Greece & Europe & Muslims, Jews \\
\hline Hungary & Europe & Muslims \\
\hline Italy & Europe & Muslims \\
\hline Netherlands & Europe & Muslims \\
\hline Poland & Europe & $\begin{array}{l}\text { Muslims, Jews, } \\
\text { Non-Christians }\end{array}$ \\
\hline Slovakia & Europe & Muslims \\
\hline Sweden & Europe & Muslims, Jews \\
\hline Switzerland & Europe & Muslims \\
\hline
\end{tabular}

SOURCE: PEW RESEARCH CENTER ANALYSis of EXTERNAL DATA (PEW RESEARCH, 2016)

(Heimlich) (Freud, 1919: 232). More specifically, the unexpected visitor arouses horror because of the uncomfortable sense of the unfamiliar within the familiar. This blurring of the boundaries between everydayness and strangeness makes the uncanny especially applicable to debates on forced displacement. Symptomatically, the refugees' arrival involves a creeping feeling of familiarity 
with people whose lives are distant from our own. Briefly, they are people just like us - "perhaps too much like us" (Macdonald, 2015).

What happens, then? The answer depends on the direction of oscillation between the familiar and the unfamiliar. If the "too much" prevails, repugnance arises. For example, when refugees are perceived and judged to be excessively similar, to the point of becoming "more like ourselves than we" (Žižek, 2008: 72), an unconscious claim of superiority will try to "refoul" the stifling commonalties with them. That sounds remarkably close to what our Muslim vigilante claimed: "We, the Bulgarian Muslims, cannot accept jihadist and islamists, people who violate our culture; we are used to living by European standards and by Bulgarian standards" (Rexhepi, 2018: 2223). This narcissistic defense against the perceived excess of equality can be paraphrased like this: all things considered, they should really not be like us, perhaps they are not even human (and then inhumane behavior and cruelty may be justified).

On the contrary, when refugees are interpreted as "just" like us, thus neutralizing the shock of intrusion, a sense of romantic closeness can prompt a reaction of compassion and care. Take, for example, the first executive order of Trump's presidency, the travel ban, that barred citizens of seven mostly Muslim nations from entering America: many protesters expressed solidarity by carrying placards bearing such messages as "We Are All Muslims Now" and "Let Them In" (The Economist, 2017: 15).

We can explain this unconditional sympathy as follows: all things considered, we are all foreigners. And we can go further, as Kristeva has done: "If I am a foreigner, then there are no foreigners" (Kristeva, 1991: 192). ${ }^{3}$

As we can easily imagine, this repugnance/compassion dialectic results in the current ambivalence of narratives about religious asylum seekers: on the one hand, religious refugees are demonized and targeted as a dangerous threat to border security; on the other hand, counter-narratives portray religious refugees as innocent victims. Religion, properly manipulated, plays therefore a pivotal role in reinforcing these two stereotypes, and in justifying two opposite

3 We agree with Kristeva in arguing that the antidote of xenophobia can occur when we recognize our "internal uncanniness". Freud's discovery of unconscious can be explained with the idea that the constituent portion of the human psyche amounts to a sort of "strangeness" within ourselves. Nevertheless, her idealistic claim of disappearance of strangeness by selfeffacement ("there are no foreigners") seems to contradict the premise ("I am a foreigner"). Besides, if the stranger would lose its strangeness - Nancy would say - what are we talking about? 
policies: in one case, refoulement practices and concentration camp-like conditions in some refugee camps or detention centers; in the other case, humanitarian camps, safe zones, resettlements in solidarity and other forms of relief actions. This oscillation between aggressive closure and humanitarian openness has been emblematically visible in Europe's Janus-faced handling of the 2015 refugee crisis, as argued by Zanfrini (2019).

Let's start by investigating the demonizing narrative: first of all, we will examine the zoopolitics, i.e., the use of animalized metaphors and imagery that pervade the rhetoric of "irregular" migrants and the violent de-humanization of refugees $(\S 3)$; secondly, our focus will be on Islamophobia (§4); thirdly, we will delve into the experience of discrimination in aid, suffered by Christian asylum seekers $(\S 5)$.

\section{$3 \quad$ Caged Animals}

Yarl's Wood is the UK's main immigration detention center. In 2014, the treatment of detainees was revealed in exclusive footage obtained by a Channel 4 News investigation. The 15-minute video revealed racism and animalization, combined with sexist objectification: to give an insight, one guard refers to detained women as "beasties" and "caged animals", suggesting that his colleague "take a stick in with you and beat them up". In another scene, a guard states nonchalantly that "these Black women... they're fucking horrible" (Canning 2017: 56).

How is it possible to imagine this de-humanization of persecuted ${ }^{4}$ people, in a country, by the way, which is often represented as a champion of human rights?

The Hoffmannian guest helps us to understand the case of Yarl's Wood: the terrifying everydayness of detained women is their obvious precariousness. That does not mean that refugees are innocent, passive victims: this is, as we will see (§6), the typical Left-liberal litany, which stands in opposition to the demonizing narrative. Precariousness is simply the basic aspect of human condition: life, all human life, is vulnerable and, therefore, ethics begins when we recognize that all lives are worth living and worth protecting. ${ }^{5}$

4 This is not to say that all refugee women have experienced sexual violence. Nevertheless, as Women for Refugee Women reported, out of 46 female interviewees who had been held in detention in the UK, 33 had been raped in their home country (Girma et al., 2014: 5-6).

5 As Butler rightly suggested, "precarity cuts across identity categories as well as multi-cultural maps" (Butler, 2009: 32). 
Conceived along these lines, it seems difficult to deny that precariousness is the truth that drives us to say: all things considered, "these Black women" are people just like us. The problem is when this radical familiarity becomes, for some people, "too much". More specifically, the problem is when we try to repudiate our own precariousness, this common truth that refugees, by just being there, remind us. If "these Black women" are nothing but the projective apparition of our disturbing, intolerable precariousness, then they must not be human like us. ${ }^{6}$ They are horrible caged animals.

This fetishist vilification is possible through an unconscious mechanism of abjection $^{7}$ and usually takes the brutal form of control: Yarl's Wood is a clear example of what Berlant has termed "hygienic governmentality" (Berlant, 1997: 175), a defensive strategy underpinned by the narrative that an abject population threatens the common good and must be rigorously governed and monitored by all sectors of society.

This zoopolitics (Vaughan-Williams, 2015: 70) ${ }^{8}$ can be particularly aggressive, especially when it is combined with the paranoid fantasy that "the only good Muslim is the bad Muslim" (Akil, 2016: 111). And that is how we arrive to measure the fear of the uncanny religious refugee: Islam is the "principal

6 As Arendt noticed (Arendt, 1976: 190), this claim of superiority is well depicted in a famous passage from Conrad's Heart of Darkness: "The earth seemed unearthly. We are accustomed to look upon the shackled form of a conquered monster, but there - there you could look at a thing monstrous and free. It was unearthly, and the men were... No, they were not inhuman. Well, you know that was the worst of it - this suspicion of their not being inhuman. It would come slowly to one. They howled and leaped and spun and made horrid faces, but what thrilled you was just the thought of their humanity - like yours - the thought of your remote kinship with this wild and passionate uproar. Ugly. Yes, it was ugly enough, but if you were man enough you would admit to yourself that there was in you just the faintest trace of a response to the terrible frankness of that noise, a dim suspicion of there being a meaning in it which you - you so remote from the night of first ages - could comprehend" (Conrad, 1988: $37-38)$.

7 "The abject - Butler argues - designates here precisely those "unlivable" and "uninhabitable" zones of social life which are nevertheless densely populated by those who do not enjoy the status of the subject, but whose living under the sign of the "unlivable" is required to circumscribe the domain of the subject. This zone of uninhabilitability will constitute the defining limit of the subject's domain; it will constitute that site of dreaded identification against which -and by virtue of which- the domain of the subject will circumscribe its own claim to autonomy and to life. In this sense, then, the subject is constituted through the force of exclusion and abjection, one which produces a constitutive outside to the subjected, an abjected outside, which is, after all, "inside" the subject as its own founding repudiation" (Butler, 1993:3).

8 Vaughan-Williams gives the shocking example of the transformation of the former zoo in Tripoli into a detention centre for predominantly Ghanaian, Nigerian, and Chadian migrants destined to Europe. Research undertaken by NG Os in Tripoli zoo, but also across Libyan processing centres, suggests the same animalization process that we have discovered in Yarl's 
catalyst" (Wilson, Mavelli, 2017:3) for increasingly harsh immigration policies and growing exclusionary discourses.

\section{$4 \quad$ Muslim Intruders}

A 2016 infamous cover of the Polish magazine $w$ Sieci showed a crude representation of what we can call a demonizing narrative of religious refugees, portrayed as hypersexualized predators (Fiddian-Qasmiyeh, 2017): a naked white blond woman, wrapped in the flag of Europe and screaming in fear, being grabbed by dark-skinned hands, with the headline "Islamic Rape of Europe" (Hart, 2017: 32). According to Pew Research Centre, the use of such rhetoric is especially common in Europe: "about a third of European countries $(33 \%)$ had nationalist parties that made political statements against religious minorities, an increase from 20\% of countries in 2015". (Pew Research Centre (2016: 7$)^{9}$ A clear example is what happened in 2015, when Hungary erected a 170-kilometre razor-wire fence along its border with Serbia. This first act was later revealed as a part of a complex plan of hygienic governmentality: Hungary further adopted two legal measures that created the category of "illegal migrant".10 The Prime Minister Viktor Orbán explained in a commentary for Frankfurt Allgemeine Zeitung his line of argument: "those arriving have been raised in another religion, and represent a radically different culture. Most of them are not Christians, but Muslims. This is an important question, because Europe and European identity is rooted in Christianity. Is it not worrying in itself that European Christianity is now barely able to keep Europe Christian?

Wood: “They (the guards) don't even enter our room because they say that we smell and that we have illnesses. They constantly insult us, and call us: "you donkey, you dog". When we are moving in their way, they look disgusted and slap us sometimes" (Amnesty, 2013:14). Obviously, anti-refugee views and ideologies are not limited to governments and politicians. The number of European countries where nongovernmental nationalist organizations targeted religious groups also increased in 2016 (Pew Research Centre, 2016: 10).

"The first was an amendment to Hungary's penal code, stating that persons entering the country without authorization -by forcing the frontier fence after September 15, 2015-are committing transgression liable to punishment by expulsion or imprisonment from one to three years. The second measure was taken by the Parliament of Hungary on September 12. At this time, a law was adopted which stipulated that military forces and police can use rubber bullets, teargas and various pyrotechnical devices to support action against migrants. Altogether, Parliament adopted a resolution providing that, in cases of emergency, authorities are entitled to make use of any kind of available measure to protect the borders of Hungary" (Kantor, Cepoi, 2018: 156). 
There is no alternative, and we have no option but to defend our borders". (Metykova, 2016: 2)

Not surprisingly, this kind of Christian fundamentalism correlates strongly with right-wing authoritarianism (Koopmans, 2015: 38 ). ${ }^{11}$ As it is known, all four Visegrad countries refused EU quotas on refugees and proclaimed the demise of Schengen (Matlary, 2018: 110-111). But the same paranoid rhetoric is pervasive across Europe. We only need to look at the list of countries where religious groups have been targeted (Pew Research, 2016:7) to see the "elephant in the room" (Betts, 2016).

Perhaps this Islamophobic backlash can be statistically correlated (Pew Research, 2018)12 to a sort of reactive Christianity, or, should we better say, "Christianist secularism" (Brubaker, 2016):13 because they are (bad) Muslims, they cannot be like us. And if they are bad, dangerous Muslims, then we, Europeans, must be, in some sense, Christians, and good Christians, perhaps not perfect, but superior to them.

That being the case, what happens to Christian refugees? Apparently, they are entitled to a better fate than that of Muslim invaders. However, the reality is quite different.

As we have just seen, the "violent Muslim invader" narrative reinforces a "toxic cocktail" (Hurd, 2017: 106) of nationalism, racism and anti-Muslim zoopolitics. During the 2016 US election, this cocktail was visible in Republican primary candidates' demonizing rhetoric about a potential threat of Syrian refugees. Two candidates, Jeb Bush and Ted Cruz, suggested that the United States should admit only Christian refugees, because "there is no meaningful risk of Christians committing acts of terror". (Meral, 2018: 5) Besides, they deserve

11 As for the Polish clergy, we need to point out that the situation is more complex: some urge the Polish Catholic Church to follow the instructions of their Pope; but others are eager to align themselves with the right-wing government's rhetoric around Muslim refugees, invasion and fear of terrorism (Narkowicz, 2018: 363).

12 This is what emerges from a 15-country survey done by the Pew Research Centre, spanning 15 Western European: both church-attending and non-practicing Christians are more likely than religiously unaffiliated adults to express anti-immigrant views. This is not to say that most Christians in Europe oppose immigration or want to keep Muslims out of their countries: "the survey data show a statistical correlation - not a clear relationship of cause and effect" (Pew Research, 2018: 78).

13 For a detailed account on the debate about secularism, see Chapter 3. 
priority, if only we consider that "Christians are the most widely targeted religion". And this is certainly true, although Muslims are not exactly that much better (Pew Research Centre, 2016: 26).

But the demonizing narrative claims that Christian's suffering is deeper, and ultimately unique. Precariousness should be differentially allocated, because not all lives are worth protecting. ${ }^{14}$

An issue, however, arises whether the heralded "preference" for Christians involves a real intention to help the most persecuted religious group in the world or not. As rightly noticed by Song (2019: 124), Trump's tough line on refugees from mostly Muslim countries has also closed the door to Christians and other religious minorities. Not surprisingly, the number of Christian refugees granted entry into the U.S. has fallen dramatically, even though Christians account for a far larger share of refugees admitted than Muslims the first half of fiscal 2018 (63\% vs. 17\%), according to a Pew Research Centre analysis of State Department data (Konnor and Krogstad, 2018).

The situation in Europe is possibly worse than in US. Take, for example, the case of Pakistani Christians. A qualitative research conducted between June and December 2015 by Madziva and Lowndes (2018) gives us an understanding of Christian asylum seekers' experiences in the UK, which is, by the way, a "Christian country", if we believe the then PM Cameron (Oliva, Hall, 2017: 54). Among the interviewees, there was a male asylum seeker who explained:

As a Christian asylum seeker from a Muslim majority country you face many obstacles in putting forward your case. The major obstacle is the place where you come from and the way you look - these are things that you can't change. Because of the way we look, immigration officials don't trust us. (...) They don't tell you openly that they are suspicious of you (...) but through their actions and body language, you can tell that you are a suspect. The problem is you can't easily separate Christians from Muslims, as we all look the same. (...) I am a Christian, but when people see me, they just conclude that I am a Muslim. So they think I have come to bomb their country. (Madziva, Lowndes, 2018: 80)

This equation of Pakistanis with bad Muslims makes it more difficult for Pakistani Christians to establish their Christian identity, and to prove their

14 As Akil argued, this instrumentalization becomes a disavowal of the meaning of suffering itself, because it denies the universal and shared precariousness: "one could assert that the singularization of one's suffering as unique and unrepeatable could also function as a repudiation of the suffering of all others" (Akil, 2016: 138). 
well-founded fear of persecution. ${ }^{15}$ That means, once again, that the rhetorical bias for Christianity is instrumental to criminalize refugees, on the whole. And this is nothing compared to what happens when Pakistani Christians come to Thailand and seek UN protection from persecution. The problem here is that Thailand has not signed the ${ }_{1951}$ UN Refugee Convention and therefore considers all refugees to be illegal immigrants. А ввС investigation has revealed that Thai officials routinely arrest and detain Christian asylum seekers, sometimes chaining them like dogs (Rogers, 2016).

And with this, we are back to where we started: how can we escape from the horrific dehumanization of zoopolitics?

An easy way is to mobilize compassion towards refugees, as opposed to demonization. (El Sheikh, 2017) But is this counter-narrative a real solution? That is what we need to address now. We begin with the left liberal litany "we are all human (refugees)" and its secularist indifference to the religious belonging of refugees (§6); we will proceed to show two dehumanizing effects of seeing refugees as helpless creatures and camping them in "humanitarian spaces":

a) the underestimation of the risks of religiously motivated attacks in refugee camps, especially against non-Muslim minorities $\left(\S_{7}\right)$;

b) the "zombification" of refugees, or the underestimation of the "agency of refugees" (Parekh, 2017) (§8).

\section{$6 \quad$ Beautiful Souls}

During the so-called long summer of migration of 2015, a great variety of campaigners ${ }^{16}$ have opposed human rights abuses and injustice against refugees. In explaining their decision to support the migrant cause, several activists framed it as a moral duty rooted in humanitarian motivations: "It is humanity. You cannot just pass by. We are all victims of a system. This feeling of injustice and insecurity harms all of us" (Milan, Pirro, 2018: 145).

As we can immediately see, "We are all victims" is the exact antithesis of "They are all Muslim intruders". In this counter-narrative, the uncanny nature of intrusion has disappeared and refugees are romantically interpreted as "just like us". Clearly, we are not arguing that mobilizations and protests, from civil disobedience to solidarity actions towards refugees (Lahusen, Grasso, 2018),

15 The truth is that Home Office tends to paint "a broad picture of Pakistanis as fraudulent and opportunistic cheats, and hence potentially bogus claimants" (Madziva, Lowndes, 2018: 87-88).

16 Supporters include many NGOs, church-based charities, established migrant organisations, left-wing academics and artists, as well as some groups within trade unions and political parties (Ataç et al., 2015: 8). 
are purely rhetorical exhibitions. On the contrary, resistance and rebellion against injustice, as we will see ( $\S 8)$, is of crucial importance from an ethical point of view. The problem is that the "We are all victims" frame is easily exploitable, especially when it becomes a typical left-wing strategy against populism or the litany of the "greatest hypocrites", as Žižek polemically likes to call those who advocate for open borders and unconditional hospitality:

secretly, they know very well this will never happen, for it would trigger an instant populist revolt in Europe. They play the Beautiful Soul, which feels superior to the corrupted world while secretly participating in it: they need the corrupted world as the only terrain where they can exert their moral superiority. (Žižek, 2016: 8)

What is relevant for our analysis is that this idealizing narrative is not only potentially hypocrite, but also indifferent to the religious dimension of forced displacement. We can identify this undervaluation of religion using the drama triangle, ${ }^{17}$ as shown in the version provided by Ruard Ganzevoort (2017: 19-20).

We have seen that the demonizing (typically right-wing) narrative frames Muslim refugees in the role of perpetrator, as a national security threat. Even if they are persecuted, their religious background takes precedence in the framing. Christian refugees are -in stark contrast- framed as innocent victims. And obviously the right-wing populists define themselves as the rescuers, claiming to be the only group that can offer the solution to stop the threat: the securitization and progressive closure of borders and the creation of detention centers to accelerate the deportation of irregular migrants.

In response, left-wing Beautiful Souls apply the drama triangle quite differently. They see their right-wing opponents as the real perpetrators, threatening and sometimes committing violence against refugees, which are now considered as victims, whether they are Muslims or Christians: they are all suffering from various discriminations, first from oppressive regimes and cruel opponents, then from traffickers and harsh immigration policies, and finally from the anti-immigration movements. The focus, therefore, is not on the religious dimension of displacement, but instead on the humanitarian one: "It is humanity", said the previously mentioned activist. And as you would expect, the (left-wing) "Beautiful Souls" cast themselves in the same role as their (rightwing) counterpart: the rescuer that takes the side of the sufferers. The relief strategy, in this case, is the production and management of hospitable spaces, such as humanitarian camps.

17 The "Drama triangle" is a model of social interaction and conflict, originally described by Karpman (1968), using the terms "perpetrator", "rescuer" and "victim". 
TABLE 2.2 The "Drama triangle"

\begin{tabular}{lll}
\hline Rescuer & Perpetrator & Victim \\
\hline $\begin{array}{lll}\text { Right-wing populists } \\
\text { Left-wing 'Beautiful Souls' }\end{array}$ & $\begin{array}{l}\text { Muslim intruders } \\
\text { Right-wing populists }\end{array}$ & $\begin{array}{l}\text { Persecuted Christians } \\
\text { All refugees }\end{array}$ \\
\hline
\end{tabular}

Paradoxically, though, this secularized humanitarian narrative, along with its humanitarian camping strategies, can have severe dehumanizing consequences, thus proving that it is not a real alternative to the zoopolitical drift. Let us look at why this happens.

\section{Re-persecuted (non-Muslim) Refugees}

The ignorance of the importance of religious belonging in the humanitarian narrative and in the practice of refugee protection, is not difficult to identify. Eghdamian (2016), who conducts a research about the minority Syrians in Jordan, has revealed a considerable lack of statistics on religious experiences, particularly those on religious minorities, in refugee camps. When he asked why the UNHCR staff he interviewed in Jordan did not take religion seriously in their understanding and assessment of Syrian refugees' needs, José Riera ${ }^{18}$ referred to the continued dominance of the secular line of thought among humanitarian actors:

It's my own view that because of the secular mind-set and the reality that many United Nations officials come from societies where faith has been pushed out of the public sphere and into a corner somewhere, we are supposed to be "blind" to faith. (Eghdamian, 2016: 453-454)

Interestingly, even a Caritas staff activist showed the same neutral position:

UNHCR does not shed light on Christians because it's a general crisis. Who is the most vulnerable? A refugee is a refugee. They (UNHCR) are

18 José Riera is senior advisor to the director of international protection, UNHCR headquarters, Geneva. 
neutral. We should all be neutral. It's what our work should be. (Eghdamian, 2016: 455)

So, where is the problem? The problem is that religious minorities could be vulnerable to reprisal attacks based on sectarian lines in refugee camps or asylum centers. (USCIRF, 2013: 6) Consequently, a religious-blind position is unable to assess needs and vulnerability among refugee population and to prevent discrimination that can emerge in displacement contexts. The cases of Sweden and Germany are tragically emblematic: as reported by Kino, ${ }^{19}$ Christians are persecuted in the Middle East and re-persecuted in asylum centers by their Muslim counterparts:

Christians are slaughtered because of their faith in Syria and Iraq. The ones that are escaping to the neighboring countries cannot be in the refugee centers because they are persecuted there as well. If they make it to Sweden and Germany they risk to be persecuted again, this time in the countries' asylum centers. (quoted in Abdelhady and Malmberg, 2019:120)

The situation in the rest of Europe is not much better and this motion for a resolution, tabled by Unhurian (2017) and other members of the Parliamentary Assembly of the Council of Europe, is a sign of serious concern:

(...) Regrettably, many refugees have continued to suffer from discrimination, violence and sometimes death because of their minority beliefs even after reaching Europe, in many cases at the hands of fellow refugees. In Resolution 2050 (2015), the Parliamentary Assembly highlighted cases where Christians have been thrown out of boats crossing the Mediterranean. There are also widespread reports of cases where refugees have been attacked for their beliefs in reception centers and refugee camps across Europe - in a 2016 report, Open Doors for instance documented hundreds of religiously motivated attacks on Christians and Yazidis in German refugee shelters. As member States are working to implement best practices to care for refugees and migrants in accordance with the core values of the Council of Europe, including equality and the

19 Nuri Kino is an award-winning Assyrian-Swedish journalist of Turkish origins who focuses on minority rights in the Middle East. In 2014, he started an organization, A Demand for Action, which attempts to provide aid to Christians in Iraq and Syria. He is also active in the Assyrian Orthodox Church. 
protection of minorities, the Assembly should closely examine this challenging reality and propose recommendations aimed at effectively protecting minorities having fled religiously motivated violence, and upholding freedom of thought, conscience and religion in reception centers and refugee camps.

It seems therefore clear that, despite the commitment for non-discrimination and care for all migrants, a secular form of hospitality could turn out to be really harmful for some religious refugees. And this is not the only dehumanizing effect of the humanitarian narrative.

Let us consider now the representation of refugees as helpless creatures. This reduction of refugees to "Muselmänner" 20 is obviously functional to emphasize the moral superiority of humanitarian rescuers: if refugees are nothing but "zombies"21, they are definitely in need of a providential savior. Obviously, the sense of desperation and helplessness is not uncommon to most refugees. ${ }^{22}$

20 The "Muselmann" appears in Primo Levi's account of his experience of the concentration camp: this slang term was used by concentration camp inmates to categorize fellow inmates who were reduced to the status of zombie, having lost "all consciousness and all personality" (Agamben, 1998: 185).

21 The thought of describing the life of refugees in refugee camps as the life of the "living dead" occurred to Bauman in 2002: "Having abandoned or been forced out of their former milieu, refugees tend to be stripped of the identities that milieu defined, sustained and reproduced. Socially, they are "zombies": their old identities survive mostly as ghosts haunting the nights all the more painfully for being all but invisible in the camp's daylight" (Bauman, 2002: 347). Interestingly, such alignment of refugees and zombies eventually became a common trope in pro-migrant narratives and accusations of dehumanisation and disregard of fellow human beings, "to the point that these lives become disposable" (Oktem, 2016). And the same plot device is used even outside academic circles: a famous Slovenian comic, Klemen Slakonja, plays Angela Merkel in a YouTube video, where the German chancellor dances with refugees made up to resemble zombies. "Refugees coming to Europe ... don't have the opportunities that they should get, so they are like the living dead here", Slakonja explained to Reuters (Reuters, 2017).

22 It is known that "refugees experiencing long transitional periods in which they are refused refugee status can develop disabling sociosomatic reaction, as exemplified by the Uppgivenhetssyndrom ("resignation syndrome") that is observed in Sweden, where hundreds of refugee children have fallen unconscious, after being informed that their families will be expelled from the country" (Ventevogel et al., 2019: 107). 
But the point is: are we sure that the life in humanitarian camps is perfectly equivalent to the life in concentration camps?

It is true that these temporary, exceptional spaces, where refugees are kept indefinitely in a "frozen transience" (Bauman, 2002: 345), come close to Goffmann's ideal type of "total institution". The ambivalent case of Zaatari camp in Jordan is telling. On the one hand, this camp typifies the negative conceptual representation of a camp: "it is an extraterritorial space of exclusion, exception, segregation, and control" (Kikano, Lizarralde, 2019: 39). On the other hand, its occupants cannot be considered as walking corpses. It is undeniable, indeed, that the camp has evolved into a city-like space, displaying a remarkable resilience. There is even an office for employment, set up in coordination with the Government of Jordan, in order to facilitate access to formal work opportunities across Jordan for refugees living in the camp (ILO, 2017).

It is impressive, but let us not deceive ourselves, Zaatari is not a wonderful haven, certainly not for young girls, increasingly targets of harassment, sexual assault, and early forced marriages. Once again, however, even these young victims are not bodies in complete submission, or a voiceless "biopolitical mass of bare life" (Bulley, 2017: 40). The story of Omaima Hoshan, a teenage Syrian refugee in Zaatari, proves it: this Malala-inspired girl is campaigning against child marriage in her refugee camp, encouraging other girls to fight the practice (Dunmore, 2016).

Briefly, it is true that humanitarian camps are sites in which refugees are closed and their bodies are potentially "abjected"; but camps are also sites of counter-conduct, in which forced displaced persons choose to stage protest activities and make use of a language of rights against the language of dehumanization. ${ }^{23}$ And fortunately, these fundamental processes of defiance are in place not only in humanitarian camps, but also in detention centers, where refugees -as we have previously commented $(\S 3)$ - are exposed to horrific animalization. Let us go back for a moment to Yarl's Wood Immigration Removal

23 It is no coincidence that, for example, there is a right to appeal against a refused asylum application. Without this fundamental right, "the state may apply its coercive power arbitrarily since this application will not be critically examined" (Kritzman-Amir and Spijkerboer, 2013: 26). In this context, the landmark case of Mss v Greece and Belgium (2011) is instructive. In its verdict, the European Court of Human Rights ruled against Greece and Belgium for "inhuman and degrading treatment" in respect of their arrangements for the detention of asylum seekers, "the first time in legal history that an EU Member State was found in breach of international humanitarian law. Moreover, the ruling was used by the ECtHR to further warn all EU national governments of the need to comply with international human rights legislation in respect of conditions of detention" (Vaughan-Williams, 2015: 26). 
Centre: in February 2018, more than 100 women have gone on hunger strike over "inhumane" conditions at the facility (Bulman, 2018). ${ }^{24}$

These micro-tactics of resistance are decisive, because they are undeniable symptoms of subjectivity: refugees are not passive victims; sometimes, they prove to be agents of rebellion against their subaltern condition. And sometimes, this open dissent can assume a political vibrancy, especially when these acts of protest become "creative breaks" (Isin, Nielsen, 2008) that re-invent ways of living together. This participatory vitality rejects the double hegemonic discourse of zoopolitics and zombipolitics, helping us to understand that the only good narrative is the narrative that refugees tell about themselves, i.e. a narrative that re-establishes their status as auctori and claimants of justice: as Bauman reminds us, refugees are "fully fledged actors in the life-drama; people, like all of us, endowed with motives that reach beyond the instinct of survival and purposes that transcend the breadline, and who engage in interaction or decline interaction, weave networks of social bonds or tear them apart" (Bauman, 2002: 343-344).

This anti-hegemonic narrative of engagement/decline of social bonds is not an easy task: it demands an ethics of "hostipitality" (Derrida, 2002: 356), ${ }^{25}$ where the tension between the unfamiliar and the familiar of refugees is never finally resolved, neither in favor of violent repulsion, nor in favor of romantic compassion. Needless to say, this ethics is possible if, and only if, we proceed on a provisional hypothesis concerning the role of religion in refugees' narrative and in their political decision to reconfigure (Sennett, 2018: 288) a livable place in exile. Our hypothesis relies on the undeniable fact that the emergence of refugee question is inseparable from, and sometimes coextensive with, religion. Suffice it to consider, as argued by Hollenbach, that "humanitarian emergencies fracture the taken-for-granted worlds of the displaced, shattering and reshaping the relationships that give meaning to the routines of ordinary life. Such crises also affect those seeking to help, who have to face the suffering of those they assist in a way that can lead to secondary trauma and burnout. Thus, humanitarian crises and forced migration-Hollenbach concludes-often raise questions about the ultimate meaning that are, in essence, religious. Is continuing to struggle pointless in the face of loss, or can one trust, however tentatively, that there is a deeper source of hope?" (Hollenbach, 2014: 454).

24 Besides, this is not the first time: in 2007 more than 100 women were involved in a hunger strike at Yarl's Wood centre and was "propelled by abusive treatment by detention centre stuff" (Conlon, 2016: 137).

25 Derrida invents the neologism of "hostipitalité" (hostipitality) in order to illustrate that hostility (which is, in Hoffmaniann terms, the structural aspect of intrusion of the "uncanny guest") is intimately intertwined with hospitality. 
Let us sketch, then, in conclusion, a four-dimensional frame for this postsecular ethics of displacement.

\section{$9 \quad$ Asylum Speakers}

In 1981, on the occasion of forming the International Committee Against Piracy, Foucault delivered a speech entitled Confronting Governments: Human Rights at the UN in Geneva. Addressing "all members of the community of the governed", he argued that the "suffering of men must never be a silent residue of policy. It grounds an absolute right to stand up and speak to those who hold power" (Foucault, 2000: 474). ${ }^{26}$

If we agree that refugees have the fundamental right to be heard, we automatically admit their ability to construct themselves as subjects through narrative (Shemak, 2011: 3-4). Briefly, at stake here is their crafting of one's self. Identity then is our first keyword that requires us to de-instrumentalize the role of religion.

Religious belonging is not reducible to a discriminatory label (bad Muslim/ good Christian refugee). When we really listen to life stories, we immediately realize that beliefs and religious affiliations are powerful signifiers for identitybuilding strategies. Furthermore, religion, especially in the case of forced displacement, becomes more and more important as a marker of demarcation and distinction from others, sometimes in a racialized and antagonistic way, sometimes in a dialectical and potentially cooperative way (Pickel, 2018: 35). That means that beliefs and religious values operate in competing ways, as they both facilitate and impede integration processes. It is therefore impossible to guarantee that religious refugees will avoid reactive solutions and behaviors, in the process of coping with uprooting and the additional burden of adaptation to a new way of life (Goździak, Shandy, 2002: 131). However, what should be guaranteed, and fostered by the States, is the favorable context in which they can express, exercise and eventually reconfigure their religious identities. This legal context is formally opened by the right to freedom of religion, which is our second keyword.

True freedom of religion must protect the fundamental aspiration of persons to gather and flourish in communities. As democratic theorists argue, the freedom of religious communities to operate in civil society serves as a crucial basis for democratic governance (Hertzke, 2013). It is also true that freedom of

26 As it is known, Foucault was referring to the specific suffering of the Vietnamese asylum seekers who had left their country after the fall of Saigon. 
religion is subject to a diversity of interpretations in its meaning and application, around the world. But from this complexity it does not follow that the concept is a Western construct, without universal meaning. The proof is that this human right is present in the Muslim world and Islam is not inherently hostile to it (Philpott, 2019).

Freedom of religion is obviously crucial in determining the refugee status. This is an interesting sentence, passed on 5 September 2012: the Court of Justice of the European Union (CJEU, 2012) points out that, "given the concept of religion also includes participation in formal worship in public, the prohibition of such participation may constitute a sufficiently serious act within the meaning of Article 9(1)(a)". ${ }^{27}$ What is important is that the Luxembourg Court rejects the common European practice of granting asylum for religious motives only in case of extreme persecution, and recognize that the freedom of religion includes the right to manifest one's faith in public and collectively (see Chapters 4 and 9).

Finally, this fundamental religious agency is highly relevant in refugees' social integration in the host society. Integration is a two-way process and can only be successfully pursued by refugees when the host society is truly hospitable to the impact of the uncanny (Robila, 2018: 2). It seems therefore clear that "government protections of religious freedom and social acceptance of diverse religious identities provide crucial leverage for inclusion of newcomers" (Hertzke, 2018: $513-514){ }^{28}$ And that is how we arrive at the third keyword: citizenship.

If we accept that religious agency is an integral part of refugees' public space making (Horstmann, Jung, 2015: 1), we must then ask ourselves: what happens when "non-citizens with extremely precarious status assert themselves as political by publicly making claims about rights and membership, freedom and equality?" (Nyers, 2008:161). This "intrusion" of religious identities and practices

27 "Everyone has the right to freedom of thought, conscience and religion; this right includes freedom to change his religion or belief and freedom, either alone or in community with others and in public or private, to manifest his religion or belief, in worship, teaching, practice and observance" (European Convention for the Protection of Human Rights and Fundamental Freedoms, art. 9(1)(a)).

28 From this inclusive point of view, the idea to prioritize the resettlement of certain religious refugees over members of other religious groups does not seem justifiable, as recently stated by the Special Rapporteur on freedom of religion and belief: "States are reminded of their obligation to provide protection to refugees and migrants, regardless of their specific religion or belief. The pretext that refugees and migrants would erode the traditional religious make-up of a country amounts to a "territorialization" of religion, which violates the spirit and the letter of the universal right to freedom of religion or belief" (Shaheed, 2018: 19). 
within public space forces us to shift our focus from citizenship as a legal status (which tends to neglect the importance of identities, participation and belonging) to performances of citizenship, i.e. creative enactments that negotiate membership, re-inventing ways of living together (Isin, Saward, 2013). The case of religious communities of Muslim immigrants in Norway is emblematic. Immigrants bring with them religious faith and practice from their countries of origin, but "the Norwegian context offers them and their offspring the opportunity to develop and choose alternative forms of associational life" (Nyhagen Predelli 2008: 256). Consider, for example, Muslim women: they are increasingly invited to participate in the mosque, which is traditionally considered as "men's arena". This new religious performance has visibly a political impact: it is no accident if Muslim women in Norway have made public calls for the reinterpretation of the Qur'an in ways that are more inclusive towards women.

It is not arbitrary, all things considered, to conclude by arguing that "migration is part of our cultural heritage" (EU, 2015: 14): "migratory peoples bring with them skills, knowledge, ideas, new approaches, entrepreneurship and cultural practices that enrich the social fabric of the communities they become part of". With this in mind, the fourth and final keyword stands out immediately: common good.

In his 1963 letter Peace on Earth, Pope John XxIII argued that "civil authority exists not to confine men within the frontiers of their own nations, but primarily to protect the common good of the State, which certainly cannot be divorced from the common good of the entire human family". (John XXIII, 1963: n. 98) That is why the Pontiff focuses on the unfairness and ill-treatment suffered by refugees, because their "incredible sufferings" (John XXIII, 1963: n. 103) are bound to have impact on both the common good of the State and the common good of the entire human family. As Hollenbach rightly points out, the marginalization of refugees' voice puts the common good in trouble: "when millions of people are forced to live under plastic sheeting and to face the dangers of cholera and other serious diseases, oftentimes for years on end, individual countries and the global human community itself are gravely wounded" (Hollenbach, 2008: 12).

Clearly, no one can offer ready-made solutions at hand. Perhaps, we need to review the assumptions of our global system. In the meantime, religious "asylum speakers" claim to be heard, and challenge the limited horizons of a statebased conception of citizenship. What is to be done? Hos(ti)pitality, surely. Not unconditionally, though. The common good criterion suggests here a necessary counterbalance to the excessive claims of rights. Indeed, we know that refugees are obliged to comply with the laws of their host country, because -as Rawls would suggests- there is "a duty of fair play": if refugees have accepted 
and intend to continue to accept the benefits of just institutions, they must do their part and not take advantage of these benefits by not cooperating (Rawls, 1999: 117). But that alone is not enough: our basic hypothesis forces us to reasonably imagine requiring refugees to share civic burdens and responsibilities, with their creative religious agency.

Without this duty to contribute to the common good of their host country, their weak, suffering voices, with their indignant claims, would remain merely lyrical, bound to disappear once again in the realm of rhetoric. But, above all, they will never become truly human storytellers of a transformative, even poetic (Derrida, 200o), public space. 